\title{
Antitumor Activity of Normal Intestinal Microflora in Human and Animals
}

Mochammad Hatta

\begin{abstract}
Abstrak
Pada penelitian ini dilakukan pemeriksaan aktifitas antitumor mikroflora normal usus manusia, mamut dan mencit, dan hasilnya menunjukkan bahwa Eubacterium, Bifidobacterium, dan Bacteroides merupakan bakteri yang dominan pada usus manusia. Sedangkan Clostridium maupun Enterobacteriaceae tidak ditemukan pada marmut. Demikian pula Clostridium dan Bifidobacterium tidak ditemukan pada mencit. Jumlah bakteri pada mencit yang mengandung tumor menurun dibandingkan dengan mencit normal. Khususnya pada ileum dari mencit yang mengandung tumor terjadi penurunan jumlah bakteri anaerob secara jelas. Dari bakteri yang ditemukan pada usus, sebanyak 59 strain yang hidup dan mati diuji aktifitas antitumornya terhadap "Ehrlich ascites tumor". Tampak bahwa 11 strain yang diuji mempunyai aktivitas antitumor. Empat diantaranya toksik terhadap "host", dan semua mencit yang diinjeksi dengan Pseudomonas aeruginosa (TYH-8) mati dalam beberapa hari. Eubacterium lentum (TYH-11), Propionibacterium acnes (TYH- 28), Proteus mirabilis (TYM-7) dan Serratia marcescens ( $T Y$ - 142) dalam bentuk hidup maupun yang diberikan formalin menunjukkan aktifitas antitumor. Kultur supernatan Serratia marcescens memperlihatkan akrifitas antitumor.
\end{abstract}

\begin{abstract}
In order to investigate the antitumor activity of intestinal microflora, the constitution of normal flora was tested in human, guinea pig and mice. It was clarified that Eubacterium. Bifidobacterium and Bacteriodes were the predominant bacterial genera in humans. In addition, neither Clostridium nor Enterobacteriaceae was detected in guinea pigs and neither Clostridium nor Bifidobacterium was present in mice. Total bacterial count in tumor-bearing mice were reduced in comparison with those in normal mice. Especially, in the ileum of tumor-bearing mice, the incidence of anaerobic bacterial genera was strikingly decreased. From the bacterial found, fifty nine (59) living and killed strains isolated from intestinal microflora were examined for their antitumor activity against Ehrlich ascites tumor. It was observed that 1$]$ of the tested strains had antitumor activity. Four of these had toxicity to the host, and especially, all mice injected with Pseudomonas aeruginosa (TYM-8), died within several days. Eubacterium lentum (TYH-1I), Propionibacterium acnes (TYM-28), Proteus mirabilis (TYM-7) and Serratia marcescens (TY-142), in which antitumor activity was recognized in living and formaline-killed bacteria, cured the tumor-bearing mice. The supernatant culture of Serratia marcescens contained apparent antitumor activity.
\end{abstract}

Keywords : Antitumor activity, normal flora, human, guinea pigs, mice.

\section{INTRODUCTION}

It is well known that in human many malignant tumors occur in digestive system, except duodenum, jejenum and ileum which very few tumors occur. Few animal tumor cell lines have been recognized from guinea pigs, while many strain are known from mice, rats and rabbits. The above two fact suggest the possibility of some form of antitumor activity common to both the human small intestine and guinea pigs from the viewpoint of the intestinal microflora, although it is also necessary to consider the structure and function of organs and tissues of the host.
The intestinal microflora has several effects on the host. Also, the bacteria constituting the normal flora show various patterns according to differences in race, age, and diet of the host. ${ }^{1,2,3}$ Furthermore, it is thought that the relation between types of food and the microflora may influence the incidence of cancer. Hill et al. ${ }^{4}$ investigated the intestinal microflora of British and American (high-risk bowel cancer) subjects and Japanese (low-risk) subject, and found that the highrisk population had a much higher proportion of Bacteriodes where as the low-risk group had a much greater proportion of Enterobacteriaceae and Streptococcus. From these findings, it was suggested that 
such differences might be related to the incidence of colon cancer.

Mastromarino et al. $^{5}$ reported that bowel cancer patients have larger number of Eubacterium and Clostridium than normal people, but no significant differences fecal anaerobic bacteria and total aerobic counts are noted.

On the other hand, Funchs et $a l^{6}{ }^{6}$ and Trock et $a l^{7}$ recognized an increased proportion of Clostridium, Lactobacillus and Streptococcus, and a decrease in Eubacterium under the influence of a high-fiber diet.

Therefore, it can be thought that antitumor activity is produced by one strain and also by cooperation of some strain of normal flora. In the present study, we investigated the constitution of bacteria of normal flora of humans, guinea pigs and mice, and antitumor activities of various isolates were examined in animal tumor experiments.

\section{MATERIALS AND METHODS}

Fecal samples : Fresh fecal samples were collected from healthy humans (16 to 46 years old) and experimental animal (guinea pigs and mice).

Animals : Male guinea pigs wheighing $350 \mathrm{~g}$ and 5-week old mala ICR mice were obtained from Sankyo Labo Service Co., Ltd., Toyama, Japan. The animals were housed under standard laboratory conditions and were given a commercial pellet diet and water ad libitum.

Media : GAM agar, BL agar, Bacteroides agar, modified FM agar ( Nissui Co., Ltd., Tokyo, Japan ), LBS agar, TGC medium (BBL Microbiology Systems, Becton Dickinson and Co., Cockeyville, MD, USA), modified VL-G, Nagler's medium and M10 were used for isolation of anaerobic bacteria, ${ }^{8}$ and $\mathrm{HI}$ agar, Blood agar, Mannitol-salt agar (Nissui Co., Ltd., Tokyo, Japan), NAC agar, Sabouraud agar (Eiken Chemical Co., Ltd., Tokyo, Japan) for aerobic bacteria.

RPMI-1640 (Nissui Co., Ltd., Tokyo, Japan) supplemented with $10 \%$ FCS was used for tumor cell culture.

Bacteriological methods : One gram of fresh fecal sample was suspended in $9 \mathrm{ml}$ of TGC medium and diluted to $1: 10$ concentration with diluent for anaerobic bacteria under a $\mathrm{CO}_{2}$ atmosphere. Total bacterial counts were determined with a modified VL-G using the rolled tube method. ${ }^{9}$

Organisms isolated from the plates were identified on the basis of colonial form, Gram staining, morphology, biochemical test and gas chromatography. ${ }^{10}$ The bacterial numbers were represented as $\log _{10}$ per gram of feces.
Antitumor activity : ICR male mice were subcutaneously inoculated with $10^{6}$ cells/animal of Ehrlich ascites tumor in RPMI-1640 supplemented with $10 \%$ FCS. On day $5,10_{6}$ cells/animal of living or formalin-killed bacterial samples were administrated intratumorally by one-shot injection or for a period of 5 days. Another mice were injected $0.1 \mathrm{ml} / \mathrm{animal}$ of supernatant culture, which had been filtered through a $0.45 \mu \mathrm{m}$ millipore filter using the same course.

The experimental period was 80 days from the inoculation of tumor cells. Tumor weight was calculated using following formula : Tumor weight $(\mathrm{mg})=$ [major axis $\mathrm{x}$ (minor axis) $\left.{ }^{2}\right\} / 2$.

\section{RESULTS}

\section{Fecal microflora}

No differences in total bacterial counts were recognized between human and animals as shown in Table 1., although the incidences of some bacterial genera showed apparent differences. Clostidium was always detected in human fecal samples, but not in those from guinea pigs and mice. Conversely, Peptostreptococci were predominant organism in guinea pigs, no coliform bacteria were detected. Bacteroidaceae were predominant bacteria in both humans and animals.

Influences of bacteria on tumors were observed in the ileum, caecum and rectum of mice. As shown in Table 2, total bacterial counts were reduced in tumorbearing mice comparison with normal mice. Particlularly, in the ileum of tumor-bearing mice, the incidence of anaerobic bacteria was decreased strikingly and only Lactobacillaceae were detectable.

Antitumor activity of isolates from feces of humans and animals

The antitumor activity against solid Ehrlich ascites tumor bacteria isolated from humans and animals is shown in Table 3.

On day 5 as many as $10^{6}$ cells of various living bacterial strains were delivered intratumorally by oneshot injection. As the results in table 4 showed eleven ${ }^{11}$ bacterial strains of 10 species showed antitumor activity against Ehrlich ascites tumor. Eubacterium lentum (TYH-11) and Clostridium perfringens (KZ-233) produced prolongation of the survival period in tumorbearing mice. Lactobacillus (TYMC-1 and KZ-1293) and Propionibacterium acnes (TYM-28) showed significant $(p<0.01)$ suppression of tumor growth. On the other hand, disappearance of tumor was observed in some tumor-bearing mice treated by the other 6 strains. These bacterial strains were then injected in- 
tratumorally for 5 days starting from day 5 . As shown in table 5, Eubacterium lentum, Propionibacterium acnes and Serratia marcescens (TY-142) showed remarkable antitumor activity, with a cured rate of more than 50\%. On the other hand, living Pseudomonas aeruginosa (TYM-8) showed toxic effect on mice which died within 10 days after inoculation of the bacilli. Clostridium perfringens, Staphylococcus aureus (TY-148) and Klebsiella oxytoca (TY-141) showed signs of toxicity which debilitated mice but did not kill them. Finally, the antitumor activity of formalin-killed cells and supernatants of 5 strains which not show toxicity were tested against Ehrlich ascites tumor. As shown in table 6, killed bacilli of 4 strains except Lactobacillus acidophilus showed a remarkable effect. In particular, killed Propionibacterium acnes, but not its supernatant culture, showed a cure rate of more than $50 \%$. With regard to Serratia marcescens, killed bacteria and supernatant culture showed cure rates of $90 \%$ and $33 \%$, respectively.

\section{DISCUSSION}

Roe and Grant ${ }^{11}$ reported that germ-free status significantly inhibited the early development of tumors following exposure to 7,12-dimethylbenzanthracene given shortly after birth, and that the induction of tumors may be influenced by gut microflora. Hill et al. ${ }^{4}$ postulated that nuclear dehydrogeneration of steroids by Clostridium paraputrificum might play on important role in the induction of colon cancer, since this metabolite is abundant in the feces of high-risk subject. ${ }^{12}$ However, Finegold et al. ${ }^{13}$ reported that there was no difference in intestinal bacterial between either cancer patients and control patients, or between subjects withn Japanese diets and those on American diets.

Our present results showed that Eubacterium, Bifidobacterium and Bacteriodes were predominant bacterial genera in human feces, but were of a low incidence of Peptostreptococci and a high incidence of Clostridium. Although, Mitsuoka et al ${ }^{14}$ reported a high incidence of the former and a low incidence of the latter. In this experiment, no Clostridium was observed in either guinea pigs or mice. With regard to this result, it was pointed out that Clostridium perfringens and Enterobacteriaceae were not detected in guinea pigs, and that Clostridium perfringens given orally could exist for only a short time in intestinal tract of guinea pigs. ${ }^{15}$

Mice had neither Clostridium nor Bifidobacterium in their intestinal microflora, but had a higher incidence and high counts of Lactobacillus than humans and guinea pigs (Table 1). These results indi- cated an apparent difference of microflora between humans and experimental animals. However, the relation between these differences and the incidence of colon cancer in humans is unknown.

Total counts of intestinal flora were decreased in tumor-bearing mice, but no change in the components of the microflora was observed except in the ileum (Table 2). This result suggest that the intestinal microflora is slightly affected by the presence of tumor. We then screened the antitumor activity of bacterial strains isolated from intestinal flora. At present, the antitumor activities of various bacterial strains are being studied by many researchers, ${ }^{16-19}$ but most of them do not exist in normal intestinal microflora. In the present paper, we recognized 11 bacterial strains which showed antitumor activity (Table 4), and four of these strains of these had a striking effect on Ehrlich ascites tumor (Table 6). However, we were unable to conclude whether all strains of these species have an antitumor effect, because no activity was observed as to different strains or sources in the same species.

As mentioned above, four species, Eubacterium lentum, Propionibacterium acnes, Proteus mirabilis (TYM-7) and Serratia marcescens, showed indisputable antitumor activity againts Ehrlich ascites tumor following administration of both living and formalin-killed cells, and also showed little toxicity on the host . As for Serratia marcescens, supernatant culture showed apparent antitumor activity. The antitumor activity of Serratia marcescens had already been reported as Coley's toxin by Natus et al. ${ }^{20}$ The antitumor activity of Propionibacterium acnes, also known as Corynebacterium parvum, was indicated by Rossol et al. ${ }^{21}$ and the antitumor activity of Proteus mirabilis against Ehrlich ascites tumor was reported by Murata et al. 22

On the other hand, as to the antitumor activity of Eubacterium lentum, we have not found any report up till now. This paper is therfore the first descriftion of the antitumor activity of Eubacterium lentum.

Mizutani and Mitsouka ${ }^{23}$ reported that liver tumorigenesis is markedly promoted with a bacteria combination of Escherichia coli, Streptococcus faecalis and Clostridium paraputrificum, and that this promoting effects is suppressed by addition of Bifidobacterium longum, Lactobacillus acidophilus and Eubacterium rectale in gnotobiotic $\mathrm{C}_{3} \mathrm{H} / \mathrm{He}$ mice. In the present expriment, Bifidobacterium longum had no antitumor activity and Lactobacillus acidophilus had a mild effect against Ehrlich ascites tumor.

These results suggested that the apperent antitumor activity of a bacterium could also vary according to the susceptibility of the target cells used. 
Table 1. Fecal bacterial flora

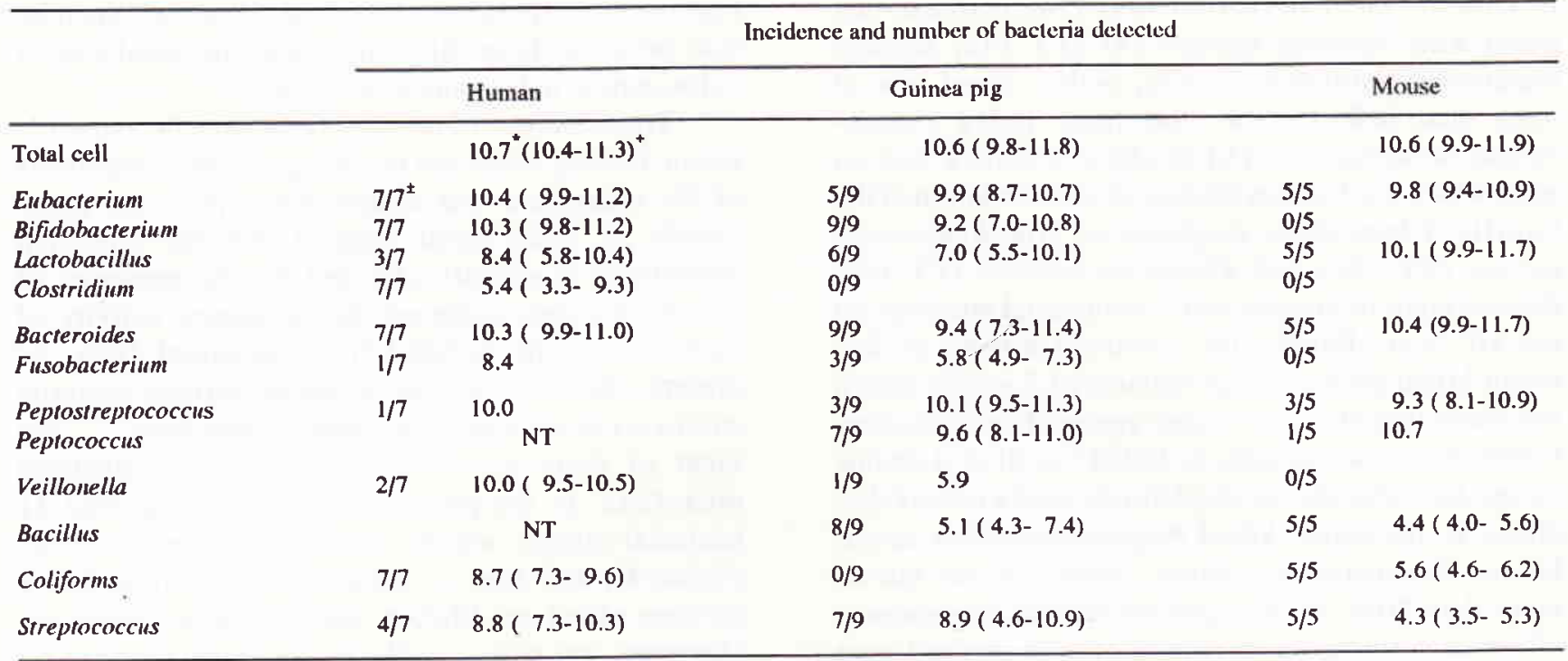

* Figures indicate the average number of bacteria cells in one gram of tecal sample and are shown by logio.

$+\quad$ Figures in parentheses indicate the range of cell numbers delected.

$\pm \quad$ Number of positif sample(s)/ number of samples tested.

NT : Not tested

Mininal levels for delection of organism is 3.00 .

Table 2. Bacterial flora in Intestine of ICR mice

\begin{tabular}{|c|c|c|c|c|c|c|c|c|c|c|c|c|}
\hline & \multicolumn{12}{|c|}{ Incidance and number of bacteria delected } \\
\hline & \multicolumn{7}{|c|}{ Normal mouse } & \multicolumn{5}{|c|}{ Tumor-bearing mouse } \\
\hline & & Ileum & & Cecum & & Rectum & & Ileum & & Cecum & & Reclum \\
\hline Toral cell & & $5^{+}(9.3-9.7) \pm$ & & $10.6(9.9-11.9)$ & & $10.6(10.2-11.5)$ & & $8.2(7.0-8.8)$ & & $9.9(9.0-10.5)$ & & $9.8(9.3-10.2)$ \\
\hline Eubacterium & $4 / 5 \S$ & $8.8(8.6-8.9)$ & $5 / 5$ & $9.8(9.4-10.9)$ & $3 / 5$ & $9.8(9.4-10.6)$ & $0 / 5$ & & $5 / 5$ & $9.1(8.3-10.1)$ & $3 / 5$ & $9.4(8.9-9.7)$ \\
\hline Bifidobacterium & $0 / 5$ & & $0 / 5$ & & $0 / 5$ & & $0 / 5$ & & $0 / 5$ & & $0 / 5$ & \\
\hline Lactobacillus & $5 / 5$ & $9.5(9.3-8.9)$ & $5 / 5$ & $10.0(9.5-10.9)$ & $5 / 5$ & $10.2(9.1-10.6)$ & $5 / 5$ & $8.2(7.0-8.9)$ & $5 / 5$ & $8.7(8.0-10.0)$ & $5 / 5$ & $8.8(8.1-9.2)$ \\
\hline Propionibacterium & $2 / 5$ & $8.2(8.0-8.4)$ & $1 / 5$ & 9.6 & $1 / 5$ & 9.3 & $0 / 5$ & & $1 / 5$ & 9.7 & $0 / 5$ & \\
\hline Clostridium & $0 / 5$ & & $0 / 5$ & & $0 / 5$ & & $0 / 5$ & & $0 / 5$ & & $0 / 5$ & \\
\hline Bacteroides & $3 / 5$ & $7.7(6.7-8.3)$ & $5 / 5$ & $10.4(9.9-11.7)$ & $5 / 5$ & $10.4(10.1-11.3)$ & $1 / 5$ & 7.2 & $5 / 5$ & $9.5(9 !-10.1)$ & $5 / 5$ & $9.0(9.1-10.1)$ \\
\hline Fusobacterium & $0 / 5$ & & $0 / 5$ & & $0 / 5$ & & $0 / 5$ & & $0 / 5$ & & $0 / 5$ & \\
\hline Peprostreprococcus & $3 / 5$ & $8.0(6.3-9.0)$ & $3 / 5$ & $9.3(8.1-10.9)$ & $2 / 5$ & $9.5(9.3-9.5)$ & $0 / 5$ & & $1 / 5$ & 8.3 & $1 / 5$ & 9.9 \\
\hline Peptococcis & $3 / 5$ & $8.9(7.9-9.2)$ & $1 / 5$ & 10.7 & $2 / 5$ & $9.3(9.0-9.6)$ & $0 / 5$ & & $1 / 5$ & 8.3 & $1 / 5$ & 9.2 \\
\hline Veillonella & $0 / 5$ & & $0 / 5$ & & $0 / 5$ & & $0 / 5$ & & $0 / 5$ & & $0 / 5$ & \\
\hline Staphylococcus & $2 / 5$ & $3.9(3.8-4.0)$ & $3 / 5$ & $3.7(3.5-4.0)$ & $5 / 5$ & $4.1(3.0-5.5)$ & $5 / 5$ & $4.2(3.0-5.4)$ & $4 / 5$ & $4.8(3.6-6.5)$ & $5 / 5$ & $4.5(3.0-5.3)$ \\
\hline Streptococcus & $4 / 5$ & $4.9(3.7-6.4)$ & $5 / 5$ & $4.3(3.5-5.3)$ & $5 / 5$ & $4.5(3.3-5.6)$ & $3 / 5$ & $4.0(3.8-4.9)$ & $5 / 5$ & $5.0(3.9-5.9)$ & $4 / 5$ & $4.6(4.2-4.9)$ \\
\hline Corynebacterium & $0 / 5$ & & $2 / 5$ & $4.6(3.7-5.5)$ & $0 / 5$ & & $0 / 5$ & & $0 / 5$ & & $0 / 5$ & \\
\hline Bacillus & $5 / 5$ & $4.4(3.5-5.4)$ & $5 / 5$ & $4.4(4.0-5.6)$ & $5 / 5$ & $4.4(4.2-4.8)$ & $5 / 5$ & $4.6(3.0-4.3)$ & $5 / 5$ & $4.2(3.6-4.9)$ & $5 / 5$ & $4.3(3.3-5.1)$ \\
\hline Escherchia & $5 / 5$ & $4.5(3.5-4.7)$ & $5 / 5$ & $5.6(4.9-6.2)$ & $5 / 5$ & $6.0(5.0-7.0)$ & $5 / 5$ & $4.6(3.0-5.7)$ & $5 / 5$ & $5.0(4,3-5.6)$ & $5 / 5$ & $5.7(4.4-7.1)$ \\
\hline Proteus & $0 / 5$ & & $0 / 5$ & & $1 / 5$ & 4.0 & $0 / 5$ & & $0 / 5$ & & $0 / 5$ & \\
\hline Pseudomonas & $1 / 5$ & 3.3 & $1 / 5$ & 3.7 & $1 / 5$ & 5.0 & $1 / 5$ & 4.3 & $2 / 5$ & $3.9(3.0-4.7)$ & $2 / 5$ & $3.9(3.0-4.8)$ \\
\hline Yeast & $1 / 5$ & 7.3 & $1 / 5$ & 7.7 & $0 / 5$ & & $0 / 5$ & & $0 / 5$ & & $0 / 5$ & \\
\hline
\end{tabular}

* Mice were given on intraperitoncal transplant of $10^{6}$ eells of Ehrlich ascites fumor and were sacrificed on day 7.

+ Figures indicate the average number of baclerial cell in one gram of fecal sample and are shown by log 10 .

\pm Figures in parentheses indicate the range of cell numbers detecled.

$\$$ Number of pexitive samples(s)/ number ol samples tested.

Minimal level for delection of organism in $\mathbf{3 . 0 0}$ 
Table 3. Bacterial samples tested for antitumor activity

\begin{tabular}{|c|c|c|c|c|}
\hline \multirow{2}{*}{ Genus } & \multicolumn{4}{|c|}{ Number of strain isolated from } \\
\hline & Human & Guinea pig & Mouse & Total \\
\hline Eubacterium & 3 & 3 & 2 & 8 \\
\hline Bifidobacrerium & 3 & 3 & & 6 \\
\hline Lactobacillus & 1 & 2 & 4 & 7 \\
\hline Propionibacterium & & & 3 & 3 \\
\hline Clostridium & 1 & & & 1 \\
\hline Bacteroides & 2 & 1 & 2 & 5 \\
\hline Fusobacterium & 2 & 3 & & 5 \\
\hline Peptostreptococcus & 2 & 3 & 1 & 6 \\
\hline Peptococcus & 4 & 2 & 2 & 8 \\
\hline Staphylococcus & 1 & & & 1 \\
\hline Streptococcus & 1 & & 1 & 2 \\
\hline Escherichia & & & 2 & 2 \\
\hline Klebsiella & 2 & & & 2 \\
\hline Proteus & & & 1 & 1 \\
\hline Serratia & 1 & & & 1 \\
\hline Pseudomonas & & & 1 & 1 \\
\hline Total & 23 & 17 & 19 & 59 \\
\hline
\end{tabular}

Table 4. Effects of bacillary samples on Elırlich ascites tumor in ICR male mice

\begin{tabular}{|c|c|c|c|c|c|}
\hline Material & Source & $\mathrm{MST}^{*}$ & $\frac{\text { No. of Survivors }}{\text { No. of tested }}$ & $\begin{array}{l}\text { Tumor size on day } 21 \\
\qquad(\mathrm{mg})\end{array}$ & $\begin{array}{l}\text { Tumor } \\
\text { growth } \\
\text { T/C (\%) }\end{array}$ \\
\hline Control & & $43.0(30-54)^{ \pm}$ & $0 / 35$ & $5858.9468 .1^{\S}$ & \\
\hline Eubacterium lentum (TYH-11) & $\mathrm{H}$ & $55.0(38-69)$ & $0 / 6$ & $4457.1 \quad 731.8$ & 76.1 \\
\hline Lactobacillus sp. (TYMC-1) & M & $60.0(51-69)$ & $0 / 6$ & $3223.3901 .7^{+}$ & 55.0 \\
\hline Lactobacillus acidophilus (KZ-1293) & $\mathrm{H}$ & $55.0(39-66)$ & $0 / 6$ & $2564.5897 .4^{++}$ & 43.8 \\
\hline Propionibacterium acnes (TYM-28) & $\mathbf{M}$ & $54.5(33-65)$ & $0 / 6$ & $2773.91387 .1^{+}$ & 47.3 \\
\hline Clostridium perfringens (KZ-223) & $\mathbf{H}$ & $48.5(33-66)$ & $0 / 4$ & 5874.91068 .8 & 100.3 \\
\hline Staphylococcus aureus (TY-148) & $\mathbf{H}$ & $52.0(51-56)$ & $1 / 6$ & $2102.8 \quad 740.2^{++}$ & 35.9 \\
\hline Escherichia coli (TY-M4) & M & $52.0(43-54)$ & $1 / 5$ & $1004.1318 .7^{++}$ & 17.1 \\
\hline Proteus mirabilis (TYM-7) & M & $61.5(49-70)$ & $1 / 5$ & $1584.5630 .1^{++}$ & 27.0 \\
\hline Klebsieel oxytoca $(\mathrm{TY}-141)$ & H & $65.0(55-69)$ & $1 / 5$ & $604.9280 .5^{++}$ & 10.3 \\
\hline Serratia marcescens (TY-142) & $\mathbf{H}$ & $56.0(43-62)$ & $1 / 5$ & $674.1454 .0^{++}$ & 11.5 \\
\hline Pseudomonas aeruginosa (TYM-8) & M & 41.0 & $2 / 3(1)^{\circ}$ & $1285.6945 .4^{t+}$ & 21.9 \\
\hline
\end{tabular}

Mice were inoculated with $10^{6}$ cells of Ehrlich ascites tumor subcutaneously and injected intratumorally with $10^{6}$ cells of bacteria by one-shot on day 5 .

* Median survival time indicates mice except those alive on day 80.

\pm Figures in parentheses indicate the range of survival time.

$\S$ Figures indicate the averange tumor size on day 21 with the mean \pm standard error.

$\sigma$ Figures in parentheses indicate the numbers of tumor-bearing mice.

,+++ : Statistical significance from the control at $\mathrm{p}<0.05$ and $\mathrm{p}<0.01$, respectively.

$\mathrm{H}$ : Human, $\mathbf{M}$ : Mouse 
Table 5. Effects of bacillary samples on Ehrlich ascites tumor in ICR male mice

\begin{tabular}{|c|c|c|c|c|}
\hline Material & $\mathrm{Mst}^{*}$ & $\frac{\text { No. of Survivors }}{\text { No. of tested }}$ & $\begin{array}{c}\text { Tumor size on day } 21 \\
\text { (mg) }\end{array}$ & $\begin{array}{l}\text { Tumor } \\
\text { growth } \\
\mathrm{T} / \mathrm{C}(\mathscr{Y})\end{array}$ \\
\hline Control & $45.0(30-55)^{ \pm}$ & $0 / 31$ & $5027.4 \pm 436.9^{8}$ & \\
\hline Eubacterium lentum (TYH-11) & $46.0(31-60)$ & $9 / 18$ & $1317.0 \pm 440.7^{++}$ & 26.2 \\
\hline Lactobacillus sp. (TYMC-1) & $43.0(32-68)$ & $2 / 18(2)^{\circ}$ & $2874.1 \pm 649.4^{++}$ & 57.2 \\
\hline Lacrobacillus acidophilus (KZ-1293) & $49.0(40-66)$ & $2 / 16$ & $1428.3 \pm 282.7^{++}$ & 28.4 \\
\hline Propionibacterinm acnes (TYM-28) & $58.5(39-63)$ & $10 / 16(2)$ & $691.2 \pm 240.4^{+t}$ & 13.7 \\
\hline Clostridium perfringens (KZ-223) & $46.5(38-65)$ & $2 / 10(1)$ & $1468.4 \pm 340.5^{++}$ & 29.2 \\
\hline Staphylococcus aureus (TY-148) & $51.5(44-65)$ & $4 / 18(3)$ & $2151.9 \pm 401.7^{++}$ & 42.8 \\
\hline Escherichia coli (TY-M4) & $49.5(40-69)$ & $4 / 18(2)$ & $1337.4 \pm 376.6^{+*}$ & 26.6 \\
\hline Profeus mirabilis (TYM-7) & $47.5(32-70)$ & $4 / 18(2)$ & $825.7 \pm 200.7^{++}$ & 16.4 \\
\hline Klebsieel oxyroca (TY-141) $)^{\Omega}$ & $52.0(45-70)$ & $3 / 18(1)$ & $1111.6 \pm 181.2^{++}$ & 22.1 \\
\hline Serratia marcescens (TY-142) & $55.0(43-66)$ & $10 / 17(1)$ & $475.5 \pm 185.6^{++}$ & 9.5 \\
\hline Pseudomonas aeruginosa (TYM-8) & 9.5 & $0 / 10$ & NT & \\
\hline
\end{tabular}

Mice were inoculated with $10^{6}$ cells of Ehrlich ascites tumor subcutaneously and injected intratumorally with $10^{6}$ cells of bacleria for 5 days from day 5 .

* Medium survival time indicates mice except those alive on day 80 .

\pm Figures in parentheses indicate the range of survival time.

$\S$ Figures indicale the averange tumor size on day 21 with the mean $\rightarrow$ standard error.

$\sigma$ Figures in parentheses indicate the numbers of tumor-bearing mice.

$\Omega$ These bacleria showed toxicily : Death, Weakness.

++ : Statislical significance from the control at $p<0.01$.

NT : Not tested

Table 6. Efrects of bacillary samples on Ehrlich ascites tumor in ICR male mice

\begin{tabular}{|c|c|c|c|c|}
\hline Material & MST $^{*}$ & $\frac{\text { No. of Survivors }}{\text { No. of Iested }}$ & $\begin{array}{l}\text { Tumor size on day } 21 \\
\text { (mg) }\end{array}$ & $\begin{array}{l}\text { Tumor } \\
\text { growlh } \\
\text { T/C(\%) }\end{array}$ \\
\hline Control & $45.0(30-60)^{ \pm}$ & $0 / 17$ & $5086.6 \pm 535.6^{8}$ & \\
\hline \multicolumn{5}{|l|}{ Eubacterium lentum } \\
\hline $\begin{array}{ll}(\mathrm{TYH}-11) & \text { killed } \\
& \text { supernantant }\end{array}$ & $\begin{array}{l}55.0(37-60) \\
40.0(28-70)\end{array}$ & $\begin{array}{l}2 / 10 \\
1 / 10\end{array}$ & $\begin{array}{l}2071.2 \pm 564.0^{+} \\
2490.3 \pm 421.8^{+}\end{array}$ & $\begin{array}{l}40.7 \\
49.0\end{array}$ \\
\hline \multicolumn{5}{|l|}{ Lactobacillus acidophilus } \\
\hline $\begin{array}{ll}\text { (KZ-1293) } & \text { killed } \\
\text { supenatant }\end{array}$ & $\begin{array}{l}52.0(39-64) \\
46.0(33-65)\end{array}$ & $\begin{array}{l}1 / 8(1)^{\circ} \\
0 / 10\end{array}$ & $\begin{array}{l}1958.8 \pm 361.0^{++} \\
3049.5 \pm 556.7^{+}\end{array}$ & $\begin{array}{l}38.5 \\
60.0\end{array}$ \\
\hline \multicolumn{5}{|l|}{ Propionibacterium acnes } \\
\hline $\begin{array}{ll}\text { (TYM-28) } & \text { killed } \\
\text { supernatant }\end{array}$ & $\begin{array}{l}64.0(63-68) \\
50.0(37-67)\end{array}$ & $\begin{array}{l}6 / 10(1) \\
0 / 10\end{array}$ & $\begin{array}{r}389.5 \pm 128.7^{++} \\
2378.1 \pm 438.9^{++}\end{array}$ & $\begin{array}{r}7.7 \\
46.8\end{array}$ \\
\hline \multicolumn{5}{|l|}{ Protens mirabilis } \\
\hline $\begin{array}{ll}\text { (TYM-7) } & \text { killed } \\
\text { supernatant }\end{array}$ & $\begin{array}{l}62.0(39-67) \\
46.0(37-68)\end{array}$ & $\begin{array}{l}4 / 10(1) \\
1 / 10\end{array}$ & $\begin{array}{rr}695.5 & \pm 04.0^{++} \\
1940.6 \pm 504.7^{++}\end{array}$ & $\begin{array}{l}13.7 \\
38.2\end{array}$ \\
\hline \multicolumn{5}{|l|}{ Serratia marcescens } \\
\hline $\begin{array}{ll}\text { (TY-142) } & \text { killed } \\
& \text { Supernatant }\end{array}$ & $\begin{array}{l}74.0 \\
65.0(40-67)\end{array}$ & $\begin{array}{l}9 / 10(3) \\
5 / 9(2)\end{array}$ & $\begin{aligned} & 148.2 \pm 28.4^{++} \\
& 353.4 \pm 174.2^{++}\end{aligned}$ & $\begin{array}{l}2.9 \\
6.9\end{array}$ \\
\hline
\end{tabular}

Mice were inoculated with $10^{6}$ cells of Ehrlich asciles tumor suhcutancously and injected intratumorally with $10^{6}$ cells of killed bacteria and $0.1 \mathrm{ml}$ or cultured supernatant.

* Median survival time indicates mice execpt those alive on day 80 .

\pm Figures in parentheses indicate the range of survival time.

$\S$ Figures indicale the averange tumor size on day 21 with the mean standard error.

$\sigma$ Figures in parentheses indicale the numbers of lumor-hearing mice.

,+++ : Statistical significance from the control at $p<0.05$ and $p<0.01$, respectively. 


\section{Acknowledgments}

I am most grateful to Dr. K. Kawai for expert help in the preparation of the manuscript and to Dr. T. Hayashi for financial support through a grant from JIMA.

\section{REFERENCES}

1. Kono S, Imanishi J, Shinchi K, Yanai F. Relationship of Diet to Small and Large Adenomas of the Sigmoid Colon. Japanese J Cancer Res 1993; 83: 13-9.

2. Moore WEC, Holdeman LV. Discussion of current bacteriological investigations of the relationships between intestinal flora, diet and colon cancer. Cancer Res 1975; 35: 3418-20.

3. Nomura A, Stemmermann GN, Chyou PH, Kato I, PerezPerez GI, Blaser MJ.Helicobacter pylory infection and gastric carcinoma among Japanese Americans in Hawaii. $\mathrm{N}$ Eng J Med 1991; 325: 1132-6.

4. Hill MJ, Drasar BS, Aries V, Crowther JS, Hawksworth G, Williams REO. Bacteria and aetiology of cancer of large bowel. Lancet; 1971: 16: 95-100.

5. Mastromarino A, Reddy BS, Wynder EL. Fecal profiles of anaerobic microflora of large bowel cancer patients with nonhereditary large bowel polyps. Cancer Res 1978; 38: 4458-62.

6. Funchs HM, Dorfman S, Floch HM. The effect of dietary fiber supplementation in man. II. Alteration in fecal physiology and bacterial flora. Am J Clin Nutr 1976; 29: 1443-7.

7. Trock B, Lanza E, Greenwald P. Dietary fiber, vegetables, and colon cancer: critical review and metanalyses of the epidemiologis evidence. J Natl Cancer Inst 1990; 82: 65061.

8. Mitsuoka T, Morishita Y, Terada A, Yamamoto S. A simple methode ("plate-in-bottle method") for cultivation of fastidious anaerobes. Japan J Microbiol 1969; 13: 383-5.

9. Cadwell D, Bryant MP. Medium without rumen fluid for nonselective enumeration and isolation of rumen bacteria. Appl Microbiol 1966; 14: 794-801.

10. Holdeman LV, Moore EEC editors. Anaerobic laboratory manual. The Virginia Polytechnic Institute and State University Anaerobe Laboratory: Balckburg. 1978.

11. Roe FJ, Grant GA. Inhibition by germ-free status of development of liver and lung tumours in mice exposed neonatally to 7,12-dimethylbenz(a)antliracene: Implications in relation to test for carcinogenicity. Int J Cancer 1970; 6: 133-44.
12. Aries VC, Goddard P, Hill MJ. Degradation of steroids by intestinal bacteria III. 3 -oxo- 5 beta-steroid theta-1 dehydrogenase and 3-oxo-5 beta-steroid theta-4 dehydrogenase. Biochim Biophys Acta 1971; 248: 482-8.

13. Finegold SM, Attebery HR, Sutter VL. Effect of diet on human fecal flora. Comparison of Japanese and American diets. Am J Clin Nutr 1974; 27 : 1456-69.

14. Mitsuoka T, Kaneuchi C. Ecology of the Bifidobacteria. Am J Clin Nutr 1971; 30: 1799-1810.

15. Yamagishi T, Konishi K, Sakamoto K, Sakurai S, Ishisaka $S$. Fate of Clostridium perfringens in intestinal of guinea pigs. Japan J Bacteriol 1981; 36: 757-65.

16. Ebina T, Murata K, Tamura K. Antitumor Effect of Intratumoral Administration of Biological Respon Modifiers: Induction of Immunosuppressive Acidic Protein, a Type of alpha-1 Acid Glycoprotein, in mice. Japanese J Cancer Res 1994; 85: 93-100.

17. Matsuzaki T, Shimizu Y, Yokokura T. Augmentation of antimetastatic effect on Lewis lung carcinoma (3LL) in C57BL/6 mice by primiting with Lactobacillus cassei. Med Microbiol Immunol 1990; 179: 161-8.

18. Fujimura H, Nanjo M, Tamura K, Saito M, Ebina T, Ishida N. Effect of OK-432, a Streptococcal preparation, on serum immunosuppresive acidic protein in tumor-bearing mice. J Clin Exp Med 1990; 152: 675-9.

19. Kataoka T, Yamamoto S, Yamamoto E, Kuramoto E, Kimura Y, Yano O, et al. Antitumor Activity of Synthetic Oligonucleotides with Sequences from cDNA Encoding Protein of Mycobacterium bovis BCG. Japanese J Cancer Res 1992; 3: 244-7.

20. Natus HC, Swift WE, Coley BL. The treatment of malignant tumors by bacterial toxins as developed by the late William B. Coley, M.D., reveiwed in the light of modem research. Cancer Res 1946; 6: 205-216.

21. Rossol S, Voth R, Brunner S, Muller WE, Buttner M, Gallati $\mathrm{H}$, et al. Corynebacterium parium (Propionibacterium acnes) : An inducer of tumor necrosis factor-alpha in human peripheral blood mononuclear cells in vitro. Eur J Immun 1990; 20: 1761-5.

22. Murata T, Arakawa M, Sugiya Y, Inazu Y, Hattori Z, Suzuki Y, et al. Oncolytic effect of Proteus mirabilis upon tumorbearing animal. Life Sciences 1965; 4: 1055-67.

23. Mizutani T, Mitsuoka T. Inhibitory effect of some intestinal bacteria on liver tumorigenesis in gnotobiotic $\mathrm{C}_{3} \mathrm{H} / \mathrm{He}$ male mice. Cancer letters 1980; 11: 89-95. 